\title{
The International Conferences on Alpine Meteorology: Characteristics and trends from a 57-year-series of scientific communication
}

\author{
H. Volkert \\ With 2 Figures \\ Received 31 October 2007; Accepted 21 February 2008 \\ Published online 30 July 2008 C Springer-Verlag 2008
}

\begin{abstract}
Summary
General information is assembled about origin, conduct and written documentation concerning the full series of 29 biennial International Conferences on Alpine Meteorology (ICAM) between 1950 and 2007. The slowly evolving format of interactive scientific communication is apparent since the series was started by Mario Bossolasco, a visionary geophysical scientist. A comparison with the related mountain meteorology conference series organized by the American Meteorological Society helps to put the European achievement in perspective. Such a compact bookkeeping activity is considered essential for valuing properly the considerable impact of a regular, focussed, single-session conference series like ICAM for issues like international cooperation, practical education of students, and scientific advancement in general.
\end{abstract}

\section{Introduction}

Science deals with a "system of knowledge concerned with the physical world and its phenomena" (www.britannica.com/dictionary; Entry: science). Debates about the acquisition of such knowledge by individuals and its dissemination

Correspondence: Hans Volkert, Deutsches Zentrum für Luft- und Raumfahrt (DLR), Institut für Physik der Atmosphäre (IPA), Oberpfaffenhofen, 82234 Wessling, Germany (E-mail: hans. volkert@dlr.de) to colleagues have a history spanning at least two millenia (cf. Zeki 2000). Conferences are "meetings of persons for discussing matters of common concern" (ditto; Entry: conference). Conferences dealing with science and with physics in particular are prominently discussed with regard to sociologic issues such as personal fairness, intercultural rules, and gender stereo-typing (cf. Langedijk 2005). Therefore it appears both useful and timely to consider the knowledge disseminating mechanisms of the multi-decadal and regular series of International Conferences on Alpine Meteorology (ICAM), which started in 1950 and recently had its 29th meeting in Chambéry, France.

Bifurcation points of scientific thought can only rarely be linked to discussions at a conference. For meteorology the double gathering in Bergen (Norway), organized by Vilhelm Bjerknes separately for all non-Germanic speakers and the remainder in the summer of 1920 right after the end of World War I, was identified as a turning point for the prevailing mainstream theories for cyclogenesis (Davies 1997). In general, scientific conferences are one of the methods for consolidating research results parallel to or before a formal publication in peer-reviewed journals. 
The unbroken series of ICAM spanning more than five decades offers the possibility of inspecting the gradual changes in conference size and format with time and attempting to generalize conclusions about the function of such medium size events for progress in atmospheric science.

This short survey has several aims. First, it sets out to recall the beginning of the ICAM series in 1950. Second, the conduct and gradually changing scope of the conferences are briefly chronicled together with a documentation of the available published material. Next, a comparison with a similar undertaking in North America makes clear what has been achieved in Europe and how an intensified cooperation across the Atlantic can provide real synergies. Then, a look to the future is attempted that takes into account the growing interest in weather and climate research in the vicinity of mountain ranges, and finally a few general conclusion are made. These points are dealt with sequentially in the following sections.

Table 1. Time series of ICAMs circling five times through half a dozen of Alpine countries with year and number, country code (cc), location and source of proceedings or volumes of extended abstracts. Sources for entries in the last column: Annalen der Meteorologie Nr. 30, pp. 369-70 (up to 1994); from internet searches for later years

\begin{tabular}{|c|c|c|c|c|c|c|c|}
\hline Year & cc & Location & Proceedings & Year & cc & Location & Proceedings \\
\hline $\begin{array}{c}1950 \\
1 \mathrm{st}\end{array}$ & I & $\begin{array}{l}\text { Milano and } \\
\text { Torino }\end{array}$ & $\begin{array}{l}\text { Geof. pura e appl. 17, } \\
1950,81-245\end{array}$ & $\begin{array}{r}1980 \\
16 \text { th }\end{array}$ & $\mathrm{F}$ & Aix-les-Bains & $\begin{array}{l}\text { Soc. Météorol. de France, } \\
\text { Boulogne-Billancourt, } \\
\text { 1980, } 462 \text { pp }\end{array}$ \\
\hline $\begin{array}{r}1952 \\
2 \mathrm{nd}\end{array}$ & A & Obergurgl & $\begin{array}{l}\text { Wetter und Leben, } \mathbf{5} \text {, } \\
\text { 1953, 1-54 }\end{array}$ & $\begin{array}{r}1982 \\
17 \text { th }\end{array}$ & $\mathrm{D}$ & Berchtesgaden & $\begin{array}{l}\text { Ann. d. Meteorologie } \\
\text { Nr. 19, 1982, } 293 \text { pp }\end{array}$ \\
\hline $\begin{array}{l}1954 \\
3 r d\end{array}$ & $\mathrm{CH}$ & Davos & $\begin{array}{l}\text { Wetter und Leben, 6, } \\
1954,187-211\end{array}$ & $\begin{array}{r}1984 \\
18 \text { th }\end{array}$ & $\begin{array}{l}\text { Y } \\
\text { (Cro) }\end{array}$ & Opatija & $\begin{array}{l}\text { Zbornik met. hidrolog. } \\
\text { radova } \mathbf{1 0}, 1984,345 \mathrm{pp}\end{array}$ \\
\hline $\begin{array}{l}1956 \\
4 \text { th }\end{array}$ & $\mathrm{F}$ & Chamonix & $\begin{array}{l}\text { La Météorologie IV, } \\
\text { 1957, 111-377 }\end{array}$ & $\begin{array}{r}1986 \\
19 \text { th }\end{array}$ & A & Rauris & $\begin{array}{l}\text { Österr. Ges. f. Meteorol., } \\
\text { Vienna, 1987, } 457 \text { pp }\end{array}$ \\
\hline $\begin{array}{l}1958 \\
5 \text { th }\end{array}$ & $\mathrm{D}$ & Garmisch & $\begin{array}{l}\text { Bericht Dt. Wetterdienst } \\
\text { Nr. 54, 1959, } 302 \text { pp }\end{array}$ & $\begin{array}{r}1988 \\
20 \text { th }\end{array}$ & I & Sestola & $\begin{array}{l}\text { Servizio Meteorol. Ital., } \\
\text { Roma } 1988\end{array}$ \\
\hline $\begin{array}{l}1960 \\
6 \text { th }\end{array}$ & $\begin{array}{l}\mathrm{Y} \\
(\text { Slo })\end{array}$ & Bled & $\begin{array}{l}\text { Hydromet. Inst. Report, } \\
\text { Beograd, 1962, } 514 \text { pp }\end{array}$ & $\begin{array}{r}1990 \\
21 \text { th }\end{array}$ & $\mathrm{CH}$ & Engelberg & $\begin{array}{l}\text { Reports MeteoSwiss } \\
\text { Nr. 48, 1990, } 437 \text { pp and } \\
\text { Nr. 49, 1991, } 135 \text { pp }\end{array}$ \\
\hline $\begin{array}{l}1962 \\
7 \text { th }\end{array}$ & I & Sestrière & $\begin{array}{l}\text { Geofisica e Meteorologia } \\
\text { II, 1963, } 303 \mathrm{pp}\end{array}$ & $\begin{array}{l}1992 \\
22 \mathrm{nd}\end{array}$ & $\mathrm{F}$ & Toulouse & $\begin{array}{l}\text { Soc. Météorol. de France, } \\
\text { 1992, } 452 \text { pp and La } \\
\text { Météorologie VII, 45, } \\
\text { 1992, 1-64 }\end{array}$ \\
\hline $\begin{array}{l}1964 \\
8 \text { th }\end{array}$ & A & Villach & $\begin{array}{l}\text { Carinthia II, special issue } \\
\text { no. } 24 \text {, Vienna, } 314 \text { pp }\end{array}$ & $\begin{array}{c}1994 \\
23 \mathrm{rd}\end{array}$ & $\mathrm{D}$ & Lindau & $\begin{array}{l}\text { Ann. d. Meteorologie } \\
\text { Nr. 30, 1994, } 370 \text { pp }\end{array}$ \\
\hline $\begin{array}{l}1966 \\
9 \text { th }\end{array}$ & $\mathrm{CH}$ & $\begin{array}{l}\text { Brig and } \\
\text { Zermatt }\end{array}$ & $\begin{array}{l}\text { Reports MeteoSwiss } \\
\text { Nr. 4, 1967, } 366 \text { pp }\end{array}$ & $\begin{array}{r}1996 \\
24 \text { th }\end{array}$ & Slo & Bled & $\begin{array}{l}\text { Hydrometeo. Inst. of } \\
\text { Slovenia, Ljubljana, } \\
1996,>303 \text { pp }\end{array}$ \\
\hline $\begin{array}{r}1968 \\
10 \text { th }\end{array}$ & $\mathrm{F}$ & Grenoble & $\begin{array}{l}\text { La Météorologie, special } \\
\text { issue, } 1969,464 \mathrm{pp}\end{array}$ & $\begin{array}{r}1998 \\
25 \text { th }\end{array}$ & I & Torino & $\begin{array}{l}\text { CIMA proceedings, } \\
\text { Torino, } 1998,>272 \mathrm{pp}\end{array}$ \\
\hline $\begin{array}{r}1970 \\
11 \text { th }\end{array}$ & $\mathrm{D}$ & Oberstdorf & $\begin{array}{l}\text { Ann. d. Meteorologie } \\
\text { Nr. 5, 1971, } 300 \mathrm{pp}\end{array}$ & $\begin{array}{r}2000 \\
26 \text { th }\end{array}$ & A & Innsbruck & $\begin{array}{l}\text { Österr. Beitr. Meteorol. } \\
\text { Geophys., issue 23, } \\
\text { 2000, on CD }\end{array}$ \\
\hline $\begin{array}{r}1972 \\
12 \text { th }\end{array}$ & $\begin{array}{l}\mathrm{Y} \\
(\mathrm{BH})\end{array}$ & Sarajevo & $\begin{array}{l}\text { Zbornik met. hidrolog. } \\
\text { radova 5, Beograd, 1973, } \\
375 \text { pp }\end{array}$ & $\begin{array}{r}2003 \\
27 \text { th }\end{array}$ & $\mathrm{CH}$ & Brig & $\begin{array}{l}\text { Online: http://www.map. } \\
\text { meteoswiss.ch/map-doc/ } \\
\text { icam2003/0th.index.htm }\end{array}$ \\
\hline $\begin{array}{r}1974 \\
13 \text { th }\end{array}$ & I & $\begin{array}{l}\text { St. Vincent } \\
\text { (Valle } \\
\text { d'Aosta) }\end{array}$ & $\begin{array}{l}\text { Riv. di Geofisica, special } \\
\text { edition, 1975, } 201 \mathrm{pp}\end{array}$ & $\begin{array}{r}2005 \\
28 \text { th }\end{array}$ & Cro & Zadar & $\begin{array}{l}\text { Online: http://www.map. } \\
\text { meteoswiss.ch/map-doc/ } \\
\text { icam2005/ }\end{array}$ \\
\hline $\begin{array}{r}1976 \\
14 \text { th }\end{array}$ & A & Rauris & $\begin{array}{l}\text { Arb. ZAMG Nr. } 32 \text { and } \\
\text { 33, Vienna, } 1978\end{array}$ & $\begin{array}{r}2007 \\
29 \text { th }\end{array}$ & $\mathrm{F}$ & Chambéry & $\begin{array}{l}\text { Online: http://www. } \\
\text { cnrm.meteo.fr/icam2007/ }\end{array}$ \\
\hline $\begin{array}{r}1978 \\
15 \text { th }\end{array}$ & $\mathrm{CH}$ & Grindelwald & $\begin{array}{l}\text { Reports MeteoSwiss } \\
\text { Nr. 40, 1978, } 332 \text { pp; } \\
\text { Nr. 41, 1979, } 63 \text { pp }\end{array}$ & $\begin{array}{r}2009 \\
30 \text { th }\end{array}$ & $\mathrm{D}$ & $\begin{array}{l}\text { Rastatt } \\
\text { (planned) }\end{array}$ & Yet to be determined \\
\hline
\end{tabular}




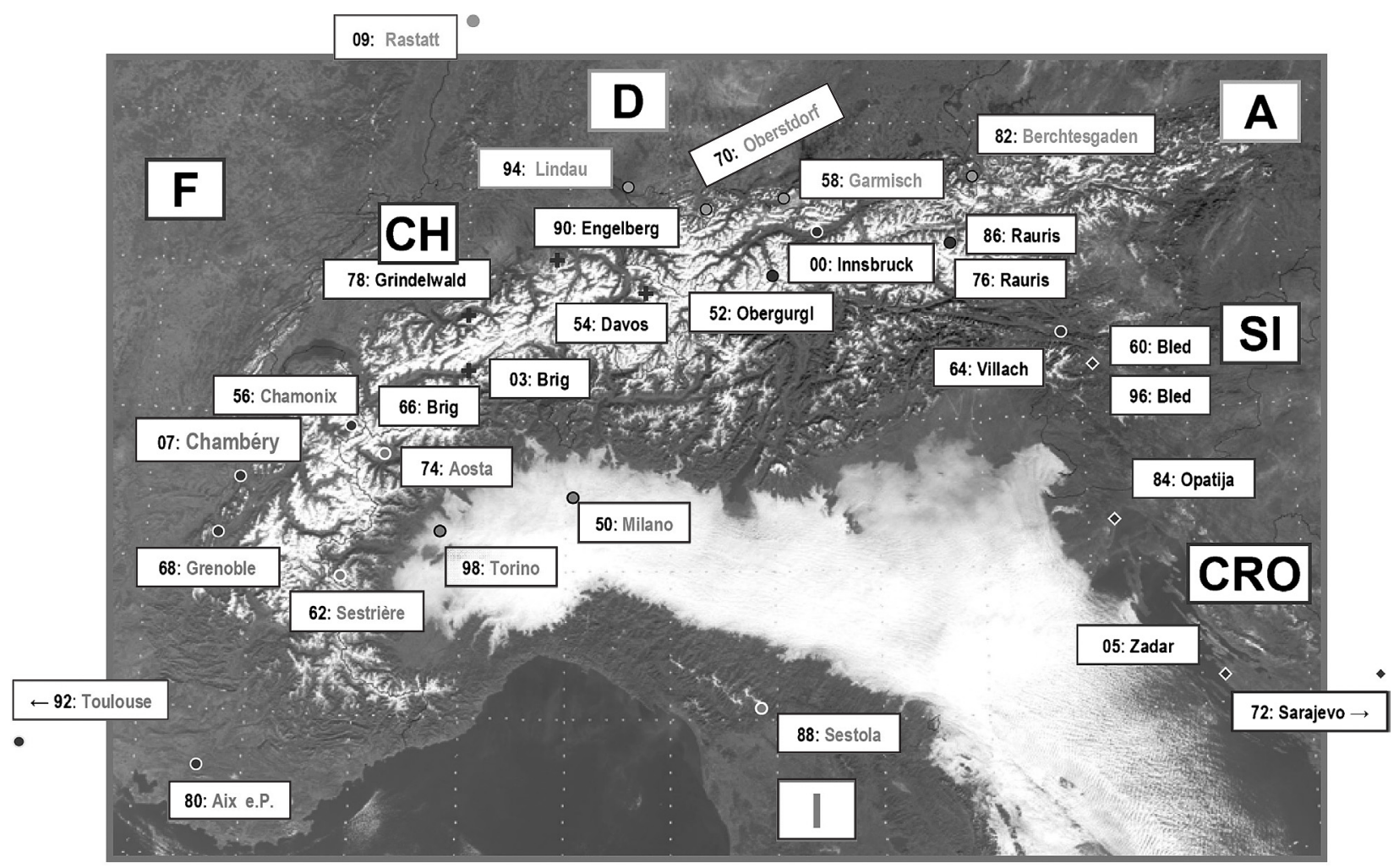

Fig. 1. Spatial distribution of the ICAM locations within the wider Alpine area shared by (now) seven Alpine countries (A, CH, CRO, D, F, I and SI) from Milano (1950) to Chambéry (2007) and Rastatt (planned for 2009; cf. Table 1). The Alpine topography of irregular snow-covered massifs separated by long, deep and snow-free valleys is visualized by a cloud-free satellite scene (except low stratus over the Po valley and the Adriatic Sea; 2 February 2002; MODIS instrument; on a stereographic projection with a $1^{\circ} \times 1^{\circ}$-dotted grid)

\section{The origin of ICAM}

The first ICAM took place in 1950 in Italy due to the personal initiative of Mario Bossolasco, who, since 1946, was a university professor and director of the Geophysical and Geodetic Institute in Genoa. Bossolasco was born on 30 June 1903 in Torino and died on 7 April 1985 in the same city (Eva 1988). After graduating in mathematics he specialized in geophysics, including seismology and meteorology. Under his initiative the research journal Geophysica Pura ed Applicata was started in 1939. This journal was renamed Pure and Applied Geophysics in 1973, after he transferred it to the Swiss publisher Birkhäuser and quit his work as editor after 34 years. Bossolasco had studied and worked abroad before World War II and was well connected in the Italian and international research communities through personal collaborations and through his work with international institutions such as WMO and IUGG.
Just five years after the end of the World War II, Bossolasco persuaded the national Istituto Geofisico Italiano to convene the Primo Convegno Internazionale di Meteorologia Alpina - the First International Conference on Alpine Meteorology (cf. Table 1 and reference therein). The conference papers were published only three months after the conference in the very journal that Bossolasco had edited since a full decade, in either Italian, English, French or German. The initiative was apparently inspired by pan-European hopes prevailing during the post-war period. Bossolasco's opening speech expressed a clear vision in which Alpine meteorology, an interdisciplinary topic at the heart of geophysics, was expected to be a prototype for post-war international cooperation. Explicit mention was made of the considerable impact of the Alps on large scale flows - like secondary cyclogenesis in the Gulf of Genoa as a result of splitting of larger cyclones coming from the Atlantic -, of the spawning of severe weather in the wake of the 
Alps, and of the Alps constituting a very special natural laboratory for a number of meteorological fields. He concluded not without pathos: "As shown by our science and its numerous applications, the Alps can help to unite the nations rather than dividing them". The topics presented at the conference included rotating tank experiments with obstacles (Fultz, USA), Föhn studies in Italy (Bossolasco, Italy), a synoptic investigation of Alpine precipitation (Striffling, France), and stratospheric flows above Europe (Hovmöller, Sweden).

The first ICAM produced sufficient momentum so that the second and third conferences were organized in Austria (1952; 128 participants) and Switzerland (1954; 129 participants). Of key importance was the active involvement of the national meteorological services and the recently founded World Meteorological Organization (WMO) as their common international body under the auspices of the newly formed United Nations. General reports and shorter abstracts of the oral presentations were published in the journal Wetter und Leben about six months after the conference (cf. Table 1). The spirit of friendship among colleagues and the very limited resources available during the first post-war decade shine through these reports.

\section{The conduct of ICAM through five Alpine cycles}

As outlined in Table 1, the other three Alpine countries France, Germany, and (former) Yugoslavia followed the founding trio, before the second cycle started in 1962, again in Italy. Like clockwork the third cycle began in 1974, the fourth in 1986, while the fifth will be completed with the 30th ICAM to take place in Germany in 2009. A nine-month-shift from September of even years to late spring of odd years took place in 2003 to establish an alternating sequence with the Mountain Meteorology Conference (MMC) series of the American Meteorological Society (AMS) and to maintain the trans-Atlantic cooperation which had developed during the conduct of the Mesoscale Alpine Programme (1995-2005; cf. Volkert and Gutermann 2007). Geographically, the Alps themselves constituted the focal area of the 27 different venues up to 2007 (Fig. 1), while neighbouring ranges were occasionally touched as well, including the Pyrenées (Toulouse 1992), the Appenines (Sestola 1988), and the Dinaric Alps (Sarajevo 1972; Opatija 1984; Zadar 2005).

An inspection of the proceedings volumes reveals a number of general points: (i) until 1976 proceedings were published well after the conference, often in quite elaborate edited layouts, (ii) from 1978 onward volumes of extended abstracts were distributed at the conference to assist all participants in selecting presentations of highest personal interest, (iii) in 1978 and 1990 Switzerland produced both on-site and resumé versions, (iv) until the 1970s all presentations were oral, leading to an increasing number of rejections (cf. Introduction to Ann. Meteorol. 5, 1970), (v) a growing number of poster presentations and the exclusive use of English became regular practise only during the late 1980s, (vi) the large mountain meteorology field campaigns ALPEX (1982), PYREX (1990), and MAP-SOP (1999) are well reflected in contributions to the following ICAMs, (vii) from 2003 onwards submission of extended abstracts via the internet greatly eased their collection, but a printed volume proved to be of unmatched value to the participants during the event, especially in comparison with the publication on a compact disc (CD).

Here it is not possible to present a thorough review of key scientific contributions in the ICAM series that eventually led to the advancement of mountain meteorology. Nevertheless a subjective selection of important explorative studies is given here (in the following the superscript $^{\mathrm{T} 1}$ refers to the appropriate volume listed in Table 1), mostly concerning topics which are still of high interest today: (i) airborne observations of mountain gravity waves (Berenger and Gerbier $1957^{\mathrm{T} 1}$ ), (ii) a study of the vertical distribution of semi-perma-frost soils within the Alps (Hastenrath $1959^{\mathrm{T} 1}$ ), (iii) high-elevation systematic measurements of direct solar radiation (Bossolasco et al. 1963 ${ }^{\mathrm{T} 1}$ ), (iv) special ground based observations in support of features detected from the new polar orbiting meteorological satellites (Kletter $1963^{\mathrm{T} 1}$; Berenger $1969^{\mathrm{T} 1}$ ), (v) airborne measurements of the diurnal variation of heating profiles in Alpine valleys (Reinhardt $1971^{\mathrm{T} 1}$ ), (vi) trials to quantify precipitation amounts in mountainous terrain by radar observations (Attmannspacher and Aniol 1971 ${ }^{\mathrm{T} 1}$ ), 
(vii) mesoscale analyses using a specialized Alpine weather chart format (Steinacker $1978^{\mathrm{T} 1}$ ), (viii) non-hydrostatic simulation of valley flows (Groß, 1982 ${ }^{\mathrm{T} 1}$ ), (ix) the dynamical impact of the Alps on the upstream flow from theoretical and observational findings (Davies, Binder and Furger $1984^{\mathrm{T} 1}$ ), (x) simulation of orographic precipitation by operational numerical weather prediction models (Binder and Wacker $1990^{\mathrm{T} 1}$ ), and (xi) a first collection of the PYREX field campaign results (Bougeault $1992^{\mathrm{T} 1}$ ) as well as challenges and prospects for an envisaged Mesoscale Alpine Programme (Volkert $1994^{\mathrm{T} 1}$ ). The full extended abstracts of the last three ICAM meetings can be viewed online (links are given in Table 1). A detailed statistical overview regard- ing the scientific presentations during the first six ICAMs was compiled by Lauscher $\left(1963^{\mathrm{T} 1}\right.$; in German).

\section{Comparison with AMS mountain meteorology conferences}

The phasing-in of ICAM with the closely related American Meteorological Society's MMCs in 2002 was mentioned above. Interestingly, this series started in 1978 with the Conference on Sierra Nevada Meteorology at Lake Tahoe, California, sponsored by the AMS and the US Forest Service. Earlier conferences related to mountain meteorology included the one-day Symposium on Mountain Meteorology in Fort

Table 2. Time series of AMS Mountain Meteorology Conferences, held mainly in the USA, with year and number, country code (cc) and state code (sc), and comments (on the preprint volumes and online access to conference programmes and extended abstracts)

\begin{tabular}{|c|c|c|c|c|c|c|c|}
\hline Year & cc, sc & Location & Comments & Year & cc, sc & Location & Comments \\
\hline $\begin{array}{c}1978 \\
1 \mathrm{st}\end{array}$ & $\begin{array}{l}\text { USA, } \\
\text { CA }\end{array}$ & $\begin{array}{l}\text { Lake } \\
\text { Tahoe }\end{array}$ & $\begin{array}{l}\text { Conference on Sierra } \\
\text { Nevada Meteorology, } \\
\text { AMS and USDA } \\
\text { Forest Service }\end{array}$ & $\begin{array}{c}1998 \\
8 \text { th }\end{array}$ & $\begin{array}{l}\text { USA, } \\
\text { AZ }\end{array}$ & Flagstaff & $\begin{array}{l}\text { Preprints, 8th Conf. on } \\
\text { Mountain Meteorology, } \\
\text { AMS, } 475 \text { pp }\end{array}$ \\
\hline $\begin{array}{c}1981 \\
2 \text { nd }\end{array}$ & $\begin{array}{l}\text { USA, } \\
\mathrm{CO}\end{array}$ & $\begin{array}{l}\text { Steamboat } \\
\text { Springs }\end{array}$ & $\begin{array}{l}\text { Preprints, 2nd Conf. on } \\
\text { Mountain Meteorology, } \\
\text { AMS, } 408 \text { pp }\end{array}$ & $\begin{array}{c}2000 \\
9 \text { th }\end{array}$ & $\begin{array}{l}\text { USA, } \\
\text { CO }\end{array}$ & Aspen & $\begin{array}{l}\text { 9th Conf. on Mountain } \\
\text { Meteorology, AMS, } 427 \mathrm{pp} \text {; } \\
\text { online at: http://ams. } \\
\text { confex.com/ams/ } \\
\text { AugAspen/techprogram/ } \\
\text { programexpanded_28.htm }\end{array}$ \\
\hline $\begin{array}{c}1984 \\
3 r d\end{array}$ & $\begin{array}{l}\text { USA, } \\
\text { OR }\end{array}$ & Portland & $\begin{array}{l}\text { Preprints, 3rd Conf. on } \\
\text { Mountain Meteorology, } \\
\text { AMS, } 233 \text { pp }\end{array}$ & $\begin{array}{r}2002 \\
10 \text { th }\end{array}$ & $\begin{array}{l}\text { USA, } \\
\text { UT }\end{array}$ & $\begin{array}{l}\text { Park } \\
\text { City }\end{array}$ & $\begin{array}{l}\text { 10th Conf. on Mountain } \\
\text { Meteorology, AMS, } 440 \text { pp. } \\
\text { Joint with MAP meeting; } \\
\text { online at: http://ams.confex. } \\
\text { com/ams/10Mountain/ } \\
\text { techprogram/ } \\
\text { programexpanded_111.htm }\end{array}$ \\
\hline $\begin{array}{c}1987 \\
4 \text { th }\end{array}$ & $\begin{array}{l}\text { USA, } \\
\text { WA }\end{array}$ & Seattle & $\begin{array}{l}\text { Preprints, 4th Conf. on } \\
\text { Mountain Meteorology, } \\
\text { AMS, } 278 \text { pp }\end{array}$ & $\begin{array}{r}2004 \\
11 \text { th }\end{array}$ & $\begin{array}{l}\text { USA, } \\
\text { NH }\end{array}$ & Barlett & $\begin{array}{l}\text { Joint with MAP meeting; } \\
\text { no published Conf. volume.; } \\
\text { online at: http://ams.confex. } \\
\text { com/ams/11Mountain/ } \\
\text { techprogram/ } \\
\text { programexpanded_237.htm }\end{array}$ \\
\hline $\begin{array}{l}1990 \\
5 \text { th }\end{array}$ & $\begin{array}{l}\text { USA, } \\
\mathrm{CO}\end{array}$ & Boulder & $\begin{array}{l}\text { Preprints, 5th Conf. on } \\
\text { Mountain Meteorology, } \\
\text { AMS, } 337 \text { pp }\end{array}$ & $\begin{array}{r}2006 \\
12 \text { th }\end{array}$ & $\begin{array}{l}\text { USA, } \\
\text { NM }\end{array}$ & Santa Fe & $\begin{array}{l}\text { No published Conf. volume; } \\
\text { online at: http://ams.confex. } \\
\text { com/ams/SantaFe2006/ } \\
\text { techprogram/ } \\
\text { programexpanded_350.htm }\end{array}$ \\
\hline $\begin{array}{c}1992 \\
6 \text { th }\end{array}$ & $\begin{array}{l}\text { USA, } \\
\text { OR }\end{array}$ & Portland & $\begin{array}{l}\text { Preprints, 6th Conf. on } \\
\text { Mountain Meteorology, } \\
\text { AMS, } 457 \text { pp }\end{array}$ & $\begin{array}{r}2008 \\
13 \text { th }\end{array}$ & $\begin{array}{l}\text { CAN, } \\
\text { British } \\
\text { Columbia }\end{array}$ & $\begin{array}{l}\text { Whistler } \\
\text { (planned) }\end{array}$ & \\
\hline $\begin{array}{c}1995 \\
7 \text { th }\end{array}$ & $\begin{array}{l}\text { USA, } \\
\text { CO }\end{array}$ & Breckenridge & $\begin{array}{l}\text { Preprints, 7th Conf. on } \\
\text { Mountain Meteorology, } \\
\text { AMS, } 390 \text { pp }\end{array}$ & & & & \\
\hline
\end{tabular}


Collins, Colorado, in 1967 (Reiter and Rasmussen 1967) and the 1976 Joint Scientific Meeting on Mountain Meteorology and Biometeorology in Interlaken, Switzerland, which was partially supported by the AMS. Up to now, there have been 12 conferences in the MMC series (Table 2). Overseen by the Mountain Meteorology committee of AMS, the earlier MMCs took place every 2 or 3 years. The alternate year phasing of this conference series with the biennial ICAM conferences has resulted in opportunities for mountain meteorologists to meet on a yearly basis on either side of the Atlantic ocean.

Since 1998 the cooperation across the Atlantic for the planning and conduct of MAP and its observing period in 1999 led to increasing participation in ICAM meetings by North American meteorologists and in MMC gatherings by European meteorologists. The enhanced level of international exchange has invigorated both conference series and has even led to some fresh ideas that are being considered for improving other AMS technical conferences (cf. also Schultz et al. 2007).

\section{The Future of ICAM}

The steady increase of submitted papers and of participants over the past four years (now regularly exceeding 200) indicates that ICAM remains firmly established as the European counterpart to the shorter series of the AMS Mountain Meteorology conferences. The sustained interest in mountain meteorology topics has led to a proposal that additional host countries be added after 2009. In June 2007, the ICAM steering committee adapted its terms of reference to invite offers from countries such as the UK and Norway. Such a widening of the perspective may broaden the focus of ICAM to include additional mountain areas and mountain research topics. This is fully in line with the Bossolasco's vision at the start of ICAM in 1950.

Planning for the 30th ICAM has already started. The provincial German town of Rastatt, situated at the river Murg in the wide Rhine valley and close to the slopes of the northern Black Forest, should offer an ideal venue within the inner observation region of the summer 2007 COPS (Convective and Orographically-induced
Precipitation Study) field campaign. COPS is listed as a research and development project of the World Weather Research Programme of WMO. Partly a heritage from MAP, COPS again drew together a large number of scientists from the USA and many European countries. ICAM is expected to maintain its presently high momentum for some years to come, as the institutional backing from the national meteorological services continues to lead to personal engagement by and scientific exchange among teams working in university institutes and in public laboratories.

\section{Conclusions}

What general conclusions can be made after a brief inspection of the complete time series spanned by 29 ICAM meetings so far? The author's personal recollection from his participation in the events 1982, 1994 and from 2000 onwards is that all ICAMs have a flavour of scientific family meetings, with modesty in presentation and in the claims of the presented results, in truly multi-lingual and multi-cultural settings. It was surprising to detect these roots extending right back to the start in 1950 .

The regularity of the unbroken biennial sequence appears remarkable, along with the full record of published conference proceedings, nearly all of them in print. It would certainly be useful to organize a full collection of the distributed conference proceedings at some institutions to ease a more systematic survey of problems, techniques, and solutions as they were documented in a preliminary fashion prior to the frequently occurring formal publication in peerreviewed journals.

On the other hand slow changes in the conference format have become evident. Within the first two decades the ICAMs also served as continuing education courses as they frequently featured lecture type presentations. During the 1970s and 1980s, participation began to necessitate a personal contribution; so the format of poster presentations was adopted along with the sole use of English for all spoken and written communications. The positive unifying and strengthening effect of large-scale cooperative field campaigns became clear together with true trans-Atlantic synergies by the official and alternating link with MMCs of AMS (cf. also Volkert 

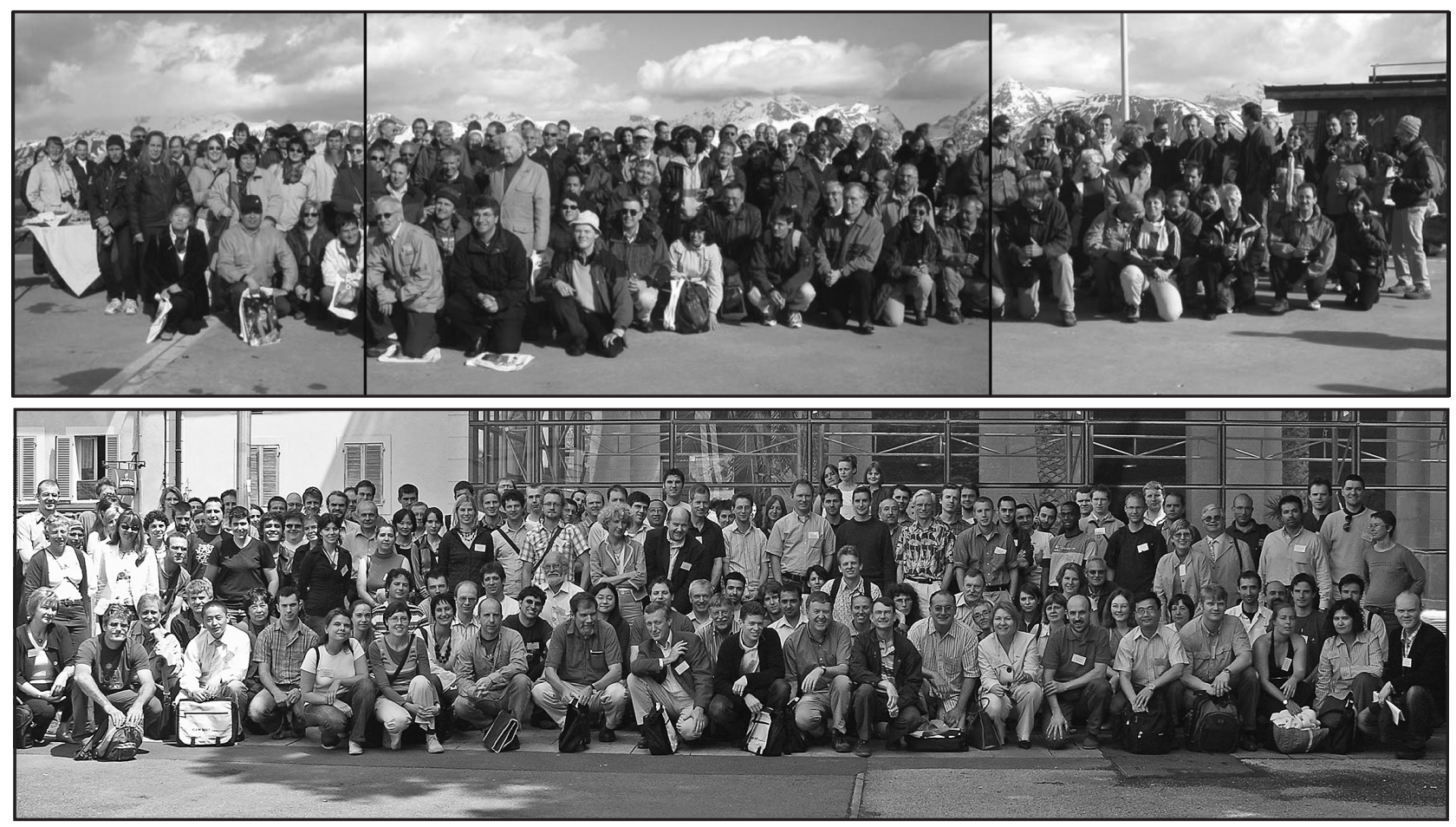

Fig. 2. Two snapshot samples displaying the majority of ICAM participants in 2003 and 2007: above - 21 May 2003 in the high Alpine setting of Kühboden/Fiescheralp above Brig (CH; photos: Brigitta Klingler); below - 6 June 2007 in an Alpine valley in front of the Chambéry conference centre (F; photo: Daniel Goetz). The considerable number of persons present at both occasions demonstrates continuity, while the variety of age groups also reflects a healthy mix of experiences from meteorological services, research laboratories and university institutes

and Gutermann 2007). As the participation from Asia and even southern hemisphere countries increases further during the coming years, the intertwined events of ICAM and MMC have the potential to develop into a global forum for mountain meteorology.

Arguably, conferences are a hidden part of the universal infrastructure in meteorology; long time series, as for ICAM, tell a historical narrative of their own; and the topics dealt with at the ICAMs touch ontologies as the various scales and techniques applied. So the pieces of atmospheric science brought together at ICAMs over more than half a century constitute a special theme in the history of weather and climate, following the recent structuring of Fleming (2006). In the end, we want to underscore that a conference is made by people for people. A glance at the participants from the gatherings in 2003 and 2007 (Fig. 2) reveals a sound mixture of younger and older scientists, of women and men as well as good continuity over time. The scientific articles within this special issue demonstrate breadth and depth of the contributions to the 29th ICAM in Chambéry and we are confident of obtaining a sustained combination of quantity with quality at the 30th ICAM in 2009.

\section{Acknowledgements}

Vincenzo Pasquale (Genova) transmitted the little known obituary of Mario Bossolasco, after Andrea Buzzi (Bologna) had pointed into the right direction. Manfred Reinhardt (Oberpfaffenhofen) provided personal memories since 1958 and original ICAM conference material from his private archive. Vanda Grubišić (Reno), Jinny Nathans (Boston) and David Whiteman (Salt Lake City) provided detailed input to Table 2 and Sect. 4. Two reviewers gave valuable hints for improvements of the presentation. All this assistance is gratefully acknowledged.

\section{References}

Davies HC (1997) Emergence of mainstream cyclogenesis theories. Meteorol Z (N.F.) 6: 261-74

Eva C (1988) Mario Bossolasco. Obituary in "Seduta Commemorativa" of 20 March 1986. Atti dell' Accademia Ligure di Scienze e Lettere 43: Genova, Italy, pp. 31-4 
Fleming JR (2006) Introduction to intimate universality: local and global themes in the history of weather and science. Science History Publications, Sagamore Beach, USA, pp. ix-xx

Lagendijk A (2005) Pushing for power. Nature 438(24 Nov): 429

Reiter ER, Rasmussen JL (1967) Proc. Symp. on Mountain Meteorology, 26 June 1967, Fort Collins, CO. Atmospheric Science Paper no. 122, Depart. Atmos. Sci., Colorado State University, Fort Collins, 221 pp
Schultz DM, Seitter K, Bosart L, Gorski C, Iovinella C (2007) Factors affecting the increasing costs of AMS conferences. Bull Amer Meteorol Soc 88: 995-9

Volkert H, Gutermann T (2007) Inter-domain cooperation for mesoscale atmospheric laboratories: the mesoscale alpine programme as a rich study case. Quart J Roy Meteorol Soc 133: 949-67

Zeki S (2000) Abstraction and idealism - from Plato to Einstein: how do we acquire knowledge? Nature 404(6 April): 547 